International Journal of Social Science And Human Research

ISSN(print): 2644-0679, ISSN(online): 2644-0695

Volume 05 Issue 01 January 2022

DOI: 10.47191/ijsshr/v5-i1-36, Impact factor-5.586

Page No: 276-280

\title{
Non-Military Defense Against Covid-19 in Bali Indonesia
}

\author{
Ketut Budiantara ${ }^{1}$, Ikhwan Syahtaria ${ }^{2}$, Dohar Siantur ${ }^{3}$, Lukman Yudho Prakoso ${ }^{4}$, \\ Herlina Juni Risma Saragih ${ }^{5}$, Ernalem Bangun ${ }^{6}$
}

${ }_{1,2,3,4,5,6}$ Repoblic Indonesia of Defense University, Kawasan IPSC Sentul, Sukahati, Kec. Citeureup, Kabupaten Bogor, Jawa Barat 16810

\begin{abstract}
The importance of strengthening non-military defense capabilities in the province of Bali as a result of the threat of the Covid-19 virus is motivated by the importance of maintaining national defense from various non-military threats, such as ideological, political, economic, socio-cultural threats, terrorism, drugs and public safety such as the spread of the Covid-19 virus. . The spread of the Covid-19 pandemic in the province of Bali is still high where as of June 9, 2021, it was recorded that the cumulative number of cases was 47,581 people, 45,630 people recovered (95.90\%), and 1,514 people died (3.18\%), 437 active cases. people $(0.92 \%)$, with the highest number of sufferers in Denpasar City with an accumulation of 15,032 sufferers. The spread of the Covid-19 virus in Bali has reduced economic growth and people's income in the tourism aspect. From these conditions, questions can be drawn about how the level of non-military Defense capability is to deal with the threat of the Covid-19 virus, alternative priorities and strategies for strengthening non-military Defense capabilities. By using quantitative research methods on non-military defense capabilities in policy/regulatory aspects (3.6), early awareness (3.9), state defense (3.9), technological capability (3.7) and budgetary support (3.5). To support the strengthening of non-military defense capabilities, it is necessary to formulate appropriate policies and establish non-military threat countermeasures institutions. The strategic step that needs to be taken is to increase the ability to analyze various potential threats in order to provide appropriate data analysis to deal with various potential military threats. As a suggestion, government action is needed to support increased national awareness to prevent risks from non-military threats.
\end{abstract}

KEYWORDS: Non-military Threat, National Defense, Covid-19, Bali, Non-military

\section{INTRODUCTION}

Efforts to improve national defense are prepared to deal with various threats including non-military threats that interfere with national defense (K. A. Prasetyo, Prakoso, \& Sianturi, 2021). In an effort to maintain national defense, not infrequently in an effort to maintain national defense, countries compete with each other for dominance in order to maintain national defense from various threats. A nation in the sociological anthropological sense is a group of people who inhabit an area bound by similarities such as the unity of race, religion/belief, tradition, history, region, customs and language (Hendrizal, 2020). From this understanding, national defense can be defined as the safety of all people who sociologically and anthropologically have ties to the unity of race, religion/belief, tradition, history, region, customs and language (Arto, 2021).

In the case of the non-military threat of the Covid-19 pandemic in Bali Province, where the growth rate of Covid-19 sufferers is still high, as of June 9, 2021, it was recorded that the cumulative number of cases was 47,581 people, 45,630 people recovered $(95.90 \%)$, and 1,514 people died. (3.18\%), active cases were 437 people $(0.92 \%)$, with the highest number of patients in Denpasar City with an accumulation of 15,032 patients (Bali, 9 June 2021). The magnitude of the case growth rate of 0.92 percent has implications for the slow handling of the spread of the Covid-19 virus which has an impact on the slow recovery of the tourism business world in Bali, which is caused by the low number of tourist visits both from domestic and abroad which has not been normal. This also has an impact on the still low income of the community and local government, especially from the tax sector, both hotel taxes, tourism sector, entertainment sector and food and beverage sector are still low. The realization of Bali Province tax revenues as of June 30, 2020 was Rp.4.32 trillion, which was dominated by Income Tax (PPh) of Rp.3.22 trillion (74.5\%) and Value Added Tax (VAT) of Rp.1.05 trillion (24.3\%). This realization is smaller than Tax Revenue in the same period in 2019 which reached Rp5.22 trillion. The decline in tax revenue is the impact of the Covid-19 pandemic (Ariwibawa, 2020)

As is the case with the Covid 19 outbreak, under certain conditions it has been wrong to predict the potential for infectious diseases to the community. The lack of comprehensive analysis of the potential threat of the COVID-19 pandemic is indicated by the idea that, firstly, the disease is unlikely to be contagious in a country that has hot weather like Indonesia. Second, some people also have the idea that Indonesian citizens have natural immunity because they often consume spices, so they are not easily infected 


\section{Non-Military Defense Against Covid-19 in Bali Indonesia}

with the Covid 19 disease. As a result of these two thoughts, some Indonesian entrepreneurs are still carrying out export and reexport activities of health equipment such as masks, medical equipment. personal protective equipment (PPE) for health workers and hand sanitizers abroad. This condition, of course, made these three items rare when the president announced that there would be Indonesian citizens infected with Covid 19 as the first and second patients on February 2, 2020. With these conditions, it is necessary to increase non-military defense capabilities to deal with the threat of the Covid-19 virus (Prakoso). , 2020).

As an analytical material, the authors use secondary data obtained from BNPB disaster report data sources, WHO report data and various main stream mass media sources in the country, especially in Bali Province. The writing of this thesis is presented using a quantitative method based on surveys and interviews with resource persons as well as secondary data and triangulation with participants related to increasing non-military defense capabilities in Bali Province in the face of the threat of the Covid-19 virus. From the results of the research, it is hoped that it will be able to provide solutions for efforts to increase non-military defense capabilities in the Province of Bali in dealing with the threat of the Covid-19 virus which can disrupt the defense of the Indonesian state.

\section{METHOD AND THEORY}

The research method used is a quantitative method to analyze various data, symptoms, information and information in increasing non-military defense capabilities in Bali Province in facing the threat of the Covid-19 pandemic. Quantitative research is defined as an analytical process to understand various conditions compiled with various theoretical studies and literature studies and data processing to produce values that support data from phenomena (Creswell, 2017). This quantitative research method was compiled by formulating various matters related to data, information and information in increasing non-military defense capabilities in Bali Province in facing the threat of the Covid-19 virus, followed by conducting a survey of various data that supports the results of quantitative research (Creswell, 2013). ). From quantitative data supported by survey activities through various data and information and compiling reports from detailed views of respondents (Creswell, 2017).

National defense is the main goal in the life of the nation and state. Marcus Tullius Ciero once said Salus populi suprema lex which means that the safety of the people is the highest law. Thus, with the establishment of a nation, the Indonesian nation has the responsibility to create security, order, welfare and prosperity for the people (A. Setiawan, 2018).

The AHP method is used to rank decision alternatives and choose the best one with several criteria. The AHP step is carried out by developing a numerical value to rank each decision alternative, based on the extent to which each alternative meets the decision maker's criteria. The AHP method is suitable for use in decision-making research models (saaty, 2008).

\section{ANALYSIS AND DISCUSSION}

From the results of data processing on 6 elements consisting of: the affected national sector, the main obstacles, possible changes, the objectives of the program to increase non-military defense in the face of the Covid-19 pandemic, the activities required and the actors involved in the implementation of the program can be described in relation to the ability to face the COVID-19 pandemic. the threat of the Covid-19 pandemic and national defense in the province of Bali.

\section{a. Affected national sectors.}

From the results of processing participant data on sector elements that are affected in strengthening non-military defense capabilities to deal with the threat of the Covid-19 virus, it is known that as a key element is the legislation sector which is carried out by drafting policies/statutory regulations in the DPR to increase non-military defense forces. This legislative activity is an important activity to formulate policies/regulations to strengthen non-military defense capabilities in the community (Robbani, Reksoprodjo, \& Bastari, 2020).

In relation to the task of preparing non-military defense capabilities in the regions, it is currently in the hands of local governments, which are supported by related agencies. Meanwhile, for countermeasures to deal with potential non-military threats, there is no agency tasked with handling them, except for disaster management, in the regions there are institutions of the Regional Disaster Management Agency (BPBD) and BNPB at the central level. Meanwhile, in the aspect of potential non-military threats in the aspects of ideology, politics, economy, socio-culture, terrorism, drugs and public safety, there is no organization/institution that handles it. With these conditions, it is important to reorganize BNPB into a BNPAN institution that has the task of dealing with the emergence of non-military threats (Lukman Yudho Prakoso, 2021).

When the non-military threat is still at the potential level, the BNPAN institution can increase the capacity of the nonmilitary aspect of state defense by conducting coaching activities to increase early awareness of local government officials and the public so that they have the ability to carry out early detection. With the ability to analyze and early detect potential non-military threats, local government officials together with the community will be able to prevent and mitigate these nonmilitary threats. To support the ability of local government officials to prevent non-military threats, it is also necessary to increase the integration between related institutions from various fields of non-military threats (Subagyo, 2018). To improve this integration, a technological facility and mastery of technology and information (ICT) are needed that integrates 


\section{Non-Military Defense Against Covid-19 in Bali Indonesia}

information from the regions to the center, so that it can be used for making the right decisions in dealing with non-military threats such as the Covid-19 pandemic.

\section{b. $\quad$ Main Obstacle}

From the results of participant data processing, the main obstacle element in strengthening non-military defense capabilities to deal with the threat of the Covid-19 virus is the low ability of the apparatus to analyze potential non-military threats, which is a key element, so that government officials and local governments need to be improved in order to be able to provide precise and accurate information. related to phenomena that occur that can disrupt the safety of the nation and national defense, such as the threat of the Covid-19 virus. The condition of the low analytical ability of government officials and regional governments in analyzing various potential non-military threats including the impact of the Covid-19 pandemic has resulted in a lack of synchrony of policies taken by local governments with the central government, so that handling the Covid-19 pandemic takes a long time (Amrynudin \& Katharina, 2020).

Thus, to be able to increase the ability of government officials and local governments in strengthening the ability of the state defense in non-military aspects to deal with the Covid-19 virus, it is necessary to increase the ability to analyze various phenomena that occur (Dipua, 2020). This analytical capability also needs to be prepared with the support of coordination with related institutions both at the regional and central levels through the media, facilities and the ability to use information and communication technology (ICT). With the integration between government officials and local governments, it is hoped that they will be able to increase public awareness up to the village/village level to comply with all instructions issued by the government and local governments (Herdiana, 2020).

Increasing public awareness and concern for complying with government and local government policies/regulations as well as the security of the surrounding environment will be able to support the ability to deal with various potential nonmilitary threats, including the Covid-19 pandemic.

\section{c. Changes that need to be made}

The results of processing participant data on elements of changes that need to be made in strengthening non-military defense capabilities to deal with the threat of the Covid-19 virus in the province of Bali, as the key to the success of the importance of BNPB organizational restructuring activities to become the National Agency for Combating Non-Military Threats (BNPAN). As described in the previous sub-chapter, this BNPAN organization is an elaborative of BNPB which is prepared to enlarge the scope of fields and responsibilities in dealing with non-military threats.

The importance of preparing the BNPAN organization is based on the consideration that potential threats to the safety of the nation can take many forms and aspects. In this non-military threat aspect, it can be in the form of ideology, politics, economy, socio-culture, legislation, drugs, cyber and public safety such as the Covid-19 pandemic. With these conditions, an institution is needed that is able to provide information for early detection, followed by early warning and early prevention (Nizar, 2021). If the potential non-military threat is unavoidable and continues to occur in the territory of Indonesia or more specifically in the province of Bali, then BNPAN is expected to be able to take appropriate steps to support the response to non-military threats (Kasih Prihantoro, 2021).

To support the organizational change of BNPB to one that handles non-military threats, it is necessary to change institutional governance against non-military threats. With this organizational change, it is necessary to formulate an organizational vision and mission to increase effectiveness in overcoming non-military threats. Apart from that, various strategies and mechanisms for cooperation with related ministries/agencies both at the central and regional levels are needed to deal with various non-military threats.

\section{d. Program Objectives.}

The results of processing participant data on the objective elements of the Non-military defense capability improvement program are known as the key element in increasing the ability of the entire Indonesian nation to face nonmilitary threats. The importance of increasing the ability of the Indonesian people in early detection, early prevention and response to potential non-military threats is the existence of conditions where the development of non-military threats such as the Covid-19 virus will have an impact on the weakening of the national defense system.

As a result of the spread of the Covid-19 pandemic which has been followed by various government policies in an effort to break the chain of distribution, such as the Large-Scale Social Restriction (PSBB) policy, the New Normal Era (New Normal) and the Enforcement of Community Activity Restrictions (PPKM), it has had various negative impacts. such as the decline in social relations in society, resulting in a decrease in production, an increase in unemployment, a decrease in people's income and a decrease in national economic growth (Prihantoro, 2021).

To improve the national defense system in the aspect of non-military threats, the government needs to develop various policy programs with the aim of increasing non-military defense capabilities which are expected to have an impact on maintaining national economic stability, which is carried out by increasing the ability to analyze various non-military threats of local government apparatus and the community, increasing public awareness of potential non-military threats, increasing 


\section{Non-Military Defense Against Covid-19 in Bali Indonesia}

integration between all personnel in ministries/agencies to deal with various potential non-military threats, mitigating various risks of non-military threats, accelerating the recovery of affected communities after the occurrence of threats and increasing community readiness to face non-military threats.

\section{e. Required activities}

The results of processing participant data on the activity elements needed to strengthen non-military defense capabilities to deal with the threat of the Covid-19 virus, as a key element are the importance of educational activities on the ability to analyze potential non-military threats and the Revision of Law Number 24 of 2007 concerning Disaster Management. Increasing the analytical capability of government apparatus and local governments in early detection of various potential non-military threats will have an impact on the accuracy and accuracy of data, so that policies and decisions taken will have effectiveness in overcoming non-military threats, including the spread of the Covid-19 pandemic. The ability of the government apparatus and supporting components such as TNI and Polri personnel will contribute to minimizing the potential risk of a greater negative impact.

Meanwhile, in the revision of Law Number 24 of 2007 concerning Disaster Management, it is necessary to revise it to deal with various potential threats to the safety of the nation. Revision of Law Number 24 of 2007 concerning Disaster Management In the management of various disasters it is necessary to make several revisions such as harmonization in the management of infectious disease outbreaks as regulated by Law Number 4 of 1984 and disasters with social conflicts which have been regulated by Law Number 7 In 2012, the revision and harmonization will be able to support effectiveness in dealing with potential threats to the safety of the nation.

The management of various potential threats to the safety of the nation can be carried out by establishing various development policies that have an impact on the occurrence of disasters, various disaster prevention activities, emergency response, and also rehabilitation. With the spread of the Covid-19 pandemic which can disrupt the safety of the Indonesian nation, governance is needed to increase vigilance in the province of Bali in order to be able to handle the dangers of the Covid-19 pandemic as part of a non-military threat that can disrupt the safety of the nation.

\section{f. Actors involved}

The results of processing participant data on elements of actors involved in strengthening non-military defense capabilities to deal with the threat of the Covid-19 virus, as a key element is the importance of the State Intelligence Agency (BIN) to provide precise and accurate analysis to the President, so that the President is able to make policies and appropriate strategic steps in accordance with the magnitude of the risk posed by the non-military threat (Suhirwan, 2020).

The role of the BIN organization in providing data, facts, risk impacts based on various phenomena and symptoms that occurred previously at the global, regional and national levels becomes a reference in compiling reports on potential threats that can disrupt the safety and security of the entire Indonesian nation. With complete, precise and accurate data and information, the President will be able to use appropriate directions and policies that will be carried out by all elements of the relevant Ministries/institutions in a targeted manner, so that the Indonesian people can mitigate or even be able to prevent the occurrence of real threats that can occur. interfere with public safety and national security.

\section{CONCLUSION}

From the description that has been described in previous chapters, a conclusion can be drawn as follows:

a.The level of non-military Defense capability in dealing with the threat of the Covid-19 virus in the province of Bali as measured by five variables, including: Policies/regulations with an average score of 3.6; Early alert with an average score of 3.9; State defense with an average score of 3.9; Technology capability with an average value of 3.7 and budget support with an average value of 3.5, when analyzed using One Way Anova, with the calculation results that Fcount $=8.8786$ and Ftable $=2.5572$, then Fcount from Ftable, meaning that Ho is rejected and Ha is accepted. This can be interpreted that there is a significant difference between the average sub-variables in strengthening the ability of non-military defense to deal with the threat of the Covid-19 virus. By looking at the value of budget support for strengthening non-military capabilities in the province of Bali in dealing with the threat of the Covid-19 virus, it is 3.5; the role of local governments is needed in supporting the tourism industry which is heavily affected by the decline in the number and activity of tourism.

b. In order to realize the strengthening of non-military defense capabilities to deal with the threat of the Covid-19 virus in the province of Bali to improve national defense, various priority steps are needed which include: formulation of appropriate policies/regulations to support strengthening of non-military defense capabilities, establishing institutions to handle strengthening non-military defense capabilities, increasing ability to analyze government officials on potential non-military threats, increase knowledge of government officials to increase non-military strength, integrate training activities for early detection of non-military threats and realize effective budget support to provide treatment, examination (Testing) and tracking (Tracking) for victims of Covid-19 19 as well as budget support for the procurement of personal protective equipment (PPE), 


\section{Non-Military Defense Against Covid-19 in Bali Indonesia}

medicines and equipment used for handling the Covid-19 pandemic. Targeted budget support to affected communities will provide effectiveness in preventing the spread of the Covid-19 pandemic in the province of Bali.

c. The strategic steps needed to support strengthening the capability of non-military defense in dealing with the threat of the Covid-19 virus in the province of Bali can be carried out with various key activities by planning legislation for policy/regulatory making to support strengthening non-military defense capabilities, increasing the ability of government officials to analyze phenomena and symptoms that can disrupt the safety of the nation, restructuring the BNPB institution so that it has a scope of tasks in tackling various non-military threats and increasing public capacity and awareness of nonmilitary defense. Activities to improve the accuracy and accuracy of the results of the analysis of various threats to national safety by BIN will contribute to the government being able to take appropriate policies to mitigate and prevent risks to national safety and security.

\section{REFERENCES}

1) Amrynudin, Anin Dhita Kiky, \& Katharina, Riris. (2020). Birokrasi Dan Kebijakan Percepatan Penanganan Covid-19. Info Singkat, 12(9), 25-30.

2) Ariwibawa, Benedictus Didik. (2020). Kajian Fiskal Regional Triwulan II 2020. Bali.

3) Arto, R. S., Prakoso, L. Y., \& Sianturi, D. (2021). Strategi Pertahanan Laut Indonesia dalam Perspektif Maritim Menghadapi Globalisasi. Strategi Pertahanan Laut, 5(2), 65-86.

4) Creswell, John W. (2017). Research design: Qualitative, quantitative, and mixed methods approaches: Sage publications.

5) Dipua, A., Hermawan, R., Puspitawati, D., Harahap, N., Rizanny, D., Prakoso, L. Y. Y., Nurdiansyah, \& Prakoso, L. Y. Y. (2020). An Analysis of The South China Sea Conflict: Indonesia's Perspectives, Contexts and Recomendations. PJAEE, $17(4), 976-990$.

6) Hendrizal. (2020). Mengulas Identitas Nasional Bangsa Indonesia Terkini. Pelita Bangsa Pelestari Pancasila, 15(1), 1-21.

7) Herdiana, Dian. (2020). Pengawasan kolaboratif dalam pelaksanaan kebijakan bantuan sosial terdampak covid-19. Jdp (jurnal dinamika pemerintahan), 3(2), 85-99.

8) Kasih Prihantoro Zakariya, Lukman Yudho Prakoso, Ratna Damayanti, A. D. (2019). Public Policy Analysis of Defense Areas and Defense Area Plan In Grati Pasuruan. The 3th Indonesia International Defense Sciense Seminar, 2(Universitas Pertahanan), 483-490.

9) Kasih Prihantoro, L. Y. P. (2021). BELA NEGARA, PERPEKTIF TEKNOLOGI PERTAHANAN. ID Patent EC00, $202,155,036$.

10) Lukman Yudho Prakoso Kasih Prihantoro, S., \& editor Suca Rusdian, M. K. (2021). Metode SWOT AHP dalam merencanakan strategi pertahanan [sumber elektronis].

11) Lukman Yudho Prakoso, Suhirwan, Kasih Prihantoro, Asep Iwa Soemantri- Editor: Budi Pramono, R. (2021). Bahan Ajar Kebijakan Pertahanan Laut (R. Budi Pramono (Ed.); 1st ed.). Unhan Press.

12) Nizar, A. A., Pramono, B., Gunawan, R., \& Prakoso, L. Y. (2021). Handling Social Conflicts in The Context of A Military Campaign Strategy ( Study in The Working Area of The Balik Papan Police Resort ). International Journal of Social Science And Human Research, 04(05), 1205-1209. https://doi.org/10.47191/ijsshr/v4-i5-40

13) Prakoso, L. Y. suhirwan; rianto; tri legionosuko; G. Z. (2021). Analysis Public Policy Of Defence Strategy. Journal of Legal, Ethical and Regulatory Issues, August. https://www.abacademies.org/articles/analysis-public-policy-of-defence-strategy.pdf

14) Prasetyo, Kuncoro Arry, Prakoso, Lukman Yudho, \& Sianturi, Dohar. (2021). Strategi Pertahanan Laut Pemerintah Indonesia dalam Menjaga Keamanan Maritim. Strategi Pertahanan Laut, 5(1).

15) Prasetyo, Kuncoro Arry, Prakoso, Lukman Yudho, \& Sianturi, Dohar. (2021). Strategi Pertahanan Laut Pemerintah Indonesia dalam Menjaga Keamanan Maritim. Strategi Pertahanan Laut, 5(1).

16) Prihantoro, K., Suhirwan, A. I. S., Pramono, B., Saputro, G. E., \& Rianto, L. Y. (n.d.). Tourism Village Government Program, Characterized By State Defense as the Economic Foundation of National Defense.

17) Robbani, Khalid S, Reksoprodjo, Agus HS, \& Bastari, Bastari. (2020). PERLINDUNGAN INFRASTRUKTUR INFORMASI KRITIKAL NASIONAL SEKTOR KETENAGALISTRIKAN DARI ANCAMAN SIBER. Peperangan Asimetris, 6(1).

18) Saaty, Thomas L. (2008). Decision making with the analytic hierarchy process. International journal of services sciences, $1(1), 83-98$.

19) Setiawan, Adam. (2018). Terlupakannya asas keselamatan rakyat adalah hokum tertinggi. https://metrojambi.com/read/2018/12/13/38164/terlupakannya-asas-keselamatan-rakyat-adalah-hukum-tertinggi/

20) Subagyo, Agus. (2018). Sinergi Dalam Menghadapi Ancaman Cyber Warfare. Jurnal Pertahanan \& Bela Negara, 5(1), 89108.

21) Suhirwan Adryan Ole, Cecep Kurniawan, L. Y. P. (2020). Indonesian Navy Against Covid-19. Public Policy And Adminstration Research, 10(IISTE), 18-23. 